\title{
REFINEMENTS OF SOME CLASSICAL INEQUALITIES ON TIME SCALES
}

\author{
RABIA BIBI
}

Abstract. In this paper we obtain refinement of the Hölder's inequality and its related inequalities including integral Minkowski's inequality and some Hardy type inequalities on time scales.

Mathematics subject classification (2020): 26D15, 34N05.

Keywords and phrases: Hölder's inequality, Minkowski's inequality, Hardy's inequality, Hilbert's inequality, time scales.

\section{REFERENCES}

[1] M. Anwar, R. Bibi, M. Bohner, AND J. PeČArić, Integral inequalities on time scales via the theory of isotonic linear functionals, Abstr. Appl. Anal., 2011, Art. ID 483595, (2011), 1-16.

[2] J. BARIĆ, R. Bibi, M. Bohner, A. NosheEn And J. PeČArić, Jensen Inequalities on Time Scales, Element, Zagreb, 2015.

[3] M. Bohner And A. Peterson, Dynamic Equations on Time Scales: An Introduction with Applications, Birkhäuser, Boston, 2001.

[4] M. Bohner And A. Peterson, Advances in Dynamic Equations on Time Scales: An Introduction with Applications, Birkhäuser, Boston, Massachusetts, 2003.

[5] M. Bohner And G. Sh. Guseinov, Multiple integration on time scales, Dynam. Systems Appl., 14, 3-4 (2005), 579-606.

[6] M. Bohner And G. Sh. Guseinov, Multiple Lebesgue integration on time scales, Adv. Difference Equ., 2006, Art. ID 26391, (2006), 1-12.

[7] X. GaO And M. GAO, A new improved form of the Hilbert inequality and its applications, Math. Inequal. Appl. 23 (2), (2020), 497-507.

[8] İ. İşCAN, New Refinements for integral and sum forms of Hölder inequality, J. Inequal. Appl., 2019, (2019), 1-11. 